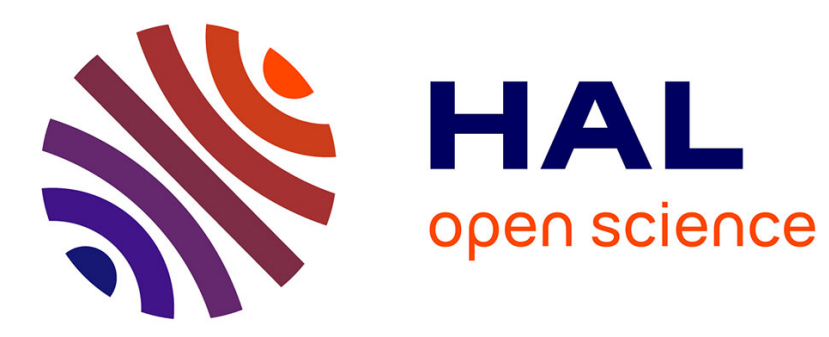

\title{
ATOMIC DATA FOR FUSION
}

H. Summers, P. Thomas, R. Giannella, M. von Hellermann

\section{To cite this version:}

H. Summers, P. Thomas, R. Giannella, M. von Hellermann. ATOMIC DATA FOR FUSION. Journal de Physique IV Proceedings, 1991, 01 (C1), pp.C1-191-C1-200. 10.1051/jp4:1991122 . jpa-00249760

\section{HAL Id: jpa-00249760 https://hal.science/jpa-00249760}

Submitted on 1 Jan 1991

HAL is a multi-disciplinary open access archive for the deposit and dissemination of scientific research documents, whether they are published or not. The documents may come from teaching and research institutions in France or abroad, or from public or private research centers.
L'archive ouverte pluridisciplinaire HAL, est destinée au dépôt et à la diffusion de documents scientifiques de niveau recherche, publiés ou non, émanant des établissements d'enseignement et de recherche français ou étrangers, des laboratoires publics ou privés. 


\author{
H.P. SUMMERS, P. THOMAS, R. GIANNELLA, M. VON HELLERMANN \& members of \\ Experimental division II
}

JET Joint Undertaking, Abington, GB-Oxon, ox14 3EA, Great-Britain

\begin{abstract}
The atomic data for fusion needs are described principally from the point of view of diagnostic spectroscopy. Tables are presented of areas of interest and associated atomic data usage. Ihese and the discussion summarise the experience and practice at the JET Joint Undertaking.
\end{abstract}

\title{
1. Introduction
}

It requires some justification to write this article in the light of the very many discussions (for example in the mecting series organised by the International Atomic Energy Authority), the extensive compilations by data centres (such as in Belfast, Oakridge and Nagoya) and generally, the very large effort worldwide on atomic studies under the banner atomic data for fusion. Nevertheless, it is the case that discussion of needs has often been anticipatory, that is generated by studies for future machines and theoretical, in the sense that the usage is in a grossed up form as an 'atomic data package' in large scale plasma simulations. There is of course a more immediate and practical side, which is experimental diagnostic studies, especially spectroscopically based, of actual working fusion machines and their atomic data requirements. The article is concerned primarily with the latter case. Inevitably it must therefore be more specific and is subjectively written from the perspective and experience of the JE' $[$ tokamak. Atomic data for diagnostics is not only more specialised but it must usually be more accurate. This is because, in reverse, the well diagnosed fusion experiment is itseif a valid source for measurement of atomic coefficients and can provide a critical reply to providers of atomic data. In this sense, the large scale plasma simulations are not a good avenue to a dialogue on atomic processes. On the other hand, it is not the purpose of this article to view the fusion plasma as merely a spectroscopic source for fundamental atomic studies. We arc concemed with a diagnostic return on important but clusive parameters of a fusion plasma to which spectroscopy and atomic physics can contribute.

\section{Table organisation}

Atomic data for JET, both current and anticipated, are summarised in tables 1 to 3 which are for ion-atom collisions, electron-ion collisions and transition probabilities respectively. Auger rates are included in the last class. Within each table a hierarchy of areas of interest are given - primary, secondary and tertiary - leading to the specific studies made at JET or planned for it. For each study, the required atomic data are identified in a final column. In the first table, the primary area is based upon the nature of the participating atoms. Tables 2 and 3 have primary arcas corresponding to important plasma zones. In the descriptive text, references will be made to the tables in the form (a.b.c.d) according to the hierarchical organisation, and the discussion is ordered broadly according to primary area. A number of works are cited in the tables. These expand on the particular study and application.

\section{Ion-atom collision data}

3.1. NEUTRAL BEAMS. - There is no doubt that the most striking advances at JFT in diagnostic spectroscopy have becn through the 'active' technique of observations of beam penetrated plasma. In $\mathrm{JF}: \mathrm{I}$, the beams are composed of neutral dcutcrium (neutral helium was used for the first time in Oct. 1990) and are in fact the heating beams. There is no separate diagnostic beam at the present on $\mathrm{Jl} \% \mathrm{Y}$. Charge transfer from the deuterium in the beam to deuterons and fully ionised impurity species in the plasma is the primary process. Consequential spectrum line emission from the recombined hydrogen-like impurity ions in the plasma is observed in visible wavelengths at various points along the beam line. The most suitable lines for observation are $\Delta n=1,2$ principal quantum shell transitions from upper shells with $n \sim 2 z_{0}^{3 / 4}$. The dominant charge transfer cross-section from deuterium in its ground state, $D(1 s)$, is into level $n_{c} \sim z_{0}^{3,4}$ so the JET observations are from high subdominant levels. The most relevant species are $\mathrm{He}, \mathrm{Bc}, \mathrm{C}$ and $\mathrm{O}$ (intrinsic impurities in JET) 
together with $B, N$ and $N_{c}$ (as possible added impurities). The beam lines at Jl: $\mathrm{T}$ operate at $40 \mathrm{keV}$; amu and $70 \mathrm{keV} / \mathrm{amu}$ primary energy at the present time and are contaminated by smaller fractions ( $15 \%$ by power) at $1 / 2$ and $1 / 3$ of the primary encrgy. Diagnostic deductions are impurity ion temperatures from the spectral line widths, plasma rotation (toroidal or poloidal) from line centre displacement and impurity densities from the line intensities. Deduction of densities requires knowledge of the attenuation of the beam to the observed volume. The attenuation and therefore beam power deposition profile is of course an important parameter for plasma performance. Total charge transfer and ionisation cross-sections are required for $D(1 \mathrm{~s})$ with all the above impurity species and deuterons (1.1./.1). The precision must be quite high, $<10 \%$ error, due to exponential amplification of the error in calculated attenuated $D(\mathrm{ls})$ densitics. The relevant encrgy range stems from the need to cope with fractional energy components and averages over the thermal distribution of plasma ions, which can be very high in recent experiments ( $\mathrm{I}_{1}<30 \mathrm{keV}$ ). For ion temperature and rotation deduction; charge exchange lines are used and the shape of the effective emission coefficient with energy is important at high thermal plasma ion temperature due to the relative collision speed variation. Line displacements close to true rotation shifts may arise simply because of this (1.1.2.1). The fundamental data is the charge exchange cross-sections into high subdominant $\mathrm{n}$-levels, which must be known absolutely for impurity density deduction (1./.2.2). Since collisional and field mixing of the l-substates is not necessarily complete, nl-resolved data is required. The greatest uncertainties are in cross-sections at energies $<40 \mathrm{keV} / \mathrm{amu}$ for high subdominant levels and 1 distributions. Cascade also matters and so projected behaviour of cross-sections to very high $\mathrm{n}$ is required. An important point is that the beam induced charge exchange lines are generally superimposed on plasma edge emitted features (1.1.2.4) which must be subtracted.

Spectral emission from deuterium (in practice $\mathrm{D} \alpha$ and $\mathrm{D} \beta$ ) in the beams can be observed. It is distinctive in that it is displaced from the stationary line position by Doppler effect in inclined viewing directions and split into separate Stark multiplets in the very large vxB electric fields ( $100 \mathrm{kV} / \mathrm{cm}$ ) in the tokamak. These reveal information on internal magnetic ficlds. The excitation of the beam atoms is by deuteron and impurity ion collisions and to a lesser extent by electron collisions. Consequently $\mathrm{D} \alpha$ Stark emission in conjunction with deuterium charge exchange emission reflects composite impurity density in the plasma. The excitation cross-sections by ions with nuclear charge $z_{0}>1$ are uncertain in the encrgy range $<50 \mathrm{keV} / \mathrm{amu}$, but are essential for the diagnostic application. The ability to deduce ground state deuterium density in the beams from the $\mathrm{D} \alpha$ emission is most important since it allows the beam attenuation to be tracked cxperimentally (1.l.1.2). Also knowledge of the excited state content of deuterium in the beams allows corrections to charge exchange based impurity density measurements by enabling inclusion of transfer from excited states (1.1.2.3). Some futher exploitation of neutral deutcrium beams arc given in table 1 .

Neutral helium beams of similar energies can also be used. In JET, some heating beams have been converted to operate with ${ }^{3} \mathrm{He}$ and ${ }^{4} \mathrm{He}$ with energics $\sim 50 \mathrm{keV} / \mathrm{amu}$ and $\sim 30 \mathrm{keV} / \mathrm{amu}$ respectivcly. Very similar atomic data to that for deuterium beams are needed but with $\mathrm{He}\left(1 \mathrm{~s}^{2} \mathrm{I}\right)$ as the donor species in the reaction (1.3.1). Helium beams may have some advantages, namely greater penetration, only a single energy component in the beam and simpler Stark features. There is a complication, namely the metastable $\mathrm{He}\left(1 \mathrm{~s} 2 \mathrm{~s}^{3} \mathrm{~S}\right)$ content of the beam. This must be minimised for power beams by $\mathrm{He}^{+} / \mathrm{He}$ ncutraliser design (1.3.3). The primary neutraliser cross-sections and subsequent He; He atom-atom cross-sections are not apparently well known. Visible spectroscopic observations of the neutraliser volume are available. Helium beams are of additional interest for measuring $\alpha$ particles by double charge transfer and then neutral particle detection (I.3.2.I).

3.2. TIIERMAL DEUTISRIUM. - Excluding the deuterium constituting the neutral bcams, neutral deuterium may be present in the plasma as; a 'halo' associated with the beam and arising from charge transfer from beam atoms to deuterons in the plasma and then their dispersion; as cvaporating pellets of solid deuterium fired into the plasma core; at the periphery of the plasma associated with gas sources and absorbing surfaces which act as a recycling reservoir. Although all these are termed thermal deuterium, evidently a number of distinct 'temperature' populations are involved as revealed even by a simple line of sight observation in $\mathrm{D} \alpha$ through the plasma in the absence of beams or pellets. We are concerned with the details of diffusion of ncutral deuterium into the plasma and its influence on gencral diagnostic spectroscopic observations of impurities. The unexpectedly high diffusion of low energy deuterium released into the plasma is due to charge transfer to more energetic deuterons (1.2.1).

Thermal deuterium as an an clectron donor to impurity ions is much different from neutral beam deuterium. The low collision speed causes the charge transfer to be strongly state selective. Such charge transfer appears to be involved in two sets of spectral observations of hydrogen-like impurity cmission. The high $\Delta \mathrm{n}=1,2$ cmission excited by charge transfer from beam deuterium is also present as a weaker less broad feature in the absence of beams or along viewing lines not intersecting beams. If charge transfer from thermal deuterium is involved in the formation of this feature, it must be from excited states of the deuterium. Also the feature may well have contributions from 
electron impact excitation and from wavelength coincident emission from lithium-like ions of the same charge state, and indeed the feature often appears to be a superposition of more than onc Gaussian. A proper understanding of the feature is necessary. The charge exchange data required is unfortunately not confidently known (l.2.l.l). A second observation is of the high members of the Lyman series of the impurities. The series decrements become markedly modified in circumstances when the thermal neutral deuterium presence might be expected to be high (plasma in contact with the walls). The primary mechanism is again probably charge transfer. A consistent model for such observations should also include the thermal $\mathrm{D}_{\alpha}$ cmission itself.

Observations of partially ionised impurity emission near the plasma edge is of great diagnostic importance for fusion plasmas and will be discussed in detail in the next section. However charge transfer from thermal neutral deuterium can again be involved in populating quite specific states. On the one hand this can perturb electron impact based interpretations but on the other hand can give direct information on the balance between charge transfer and electron processes for such ions. Accurate state selective charge transfer cross-sections at thermal energies are essential but ayain appear to be a disputed area (1.2.3.1).

\section{Electron-ion collision data}

4.1. EDGE PLASMA. - In this area, the plasma is interacting strongly with the solid surfaces which bound it. In the 'scrape-off-layer', the magnetic field structures are open and there are strong flows of particles to the limiting surfaces. From these surfaces, impurities are released back into the plasma. Temperature and density gradients are large. It is the most dynamic and complex region of the plasma from an atomic physics point of view and is strongly influential on the central 'bulk' plasma. It is also the most difficult to diagnose. The atomic processes in the edge plasma are essentially electron collision dominated apart from the neutral deuterium influences described in the last section.

Deduction of influxes of intrinsic light impurities ( $\mathrm{Be}, \mathrm{C}, \mathrm{O}$ ) is from visible spectral observations along many lines of sight directed at particular surfaces of the singly and doubly ionised ions. They are ionised quite locally to the surface which is their sourcc. Visible transitions occur between higher principal quantum shells of these ions and this determines the excitation data required (2.1.1.1), that is $n=2-2,2-3$ and $3-3$. The non-dipole cross-sections must be included to give favourable branching for visible lines and the 3-3 cross-sections are required because of collisional-radiative mixing processes at typical edge densities. Because of the highly dynamic state, cach metastable of an inflowing ion must be viewed as having an independent population to be characterised by a spectrum line observation. $\mathrm{C}^{+2}$ therefore requires a singlet and triplet line observation to deduce its flux. Linfortunately, detailed cross-section calculations involving excited $\mathrm{n}$-shells for low ionisation stages seem to have been left behind in the advance to ever higher charge states and heavier elements. The derived quantity which reduces the observed emission to a particle flux is called a 'photon cfficiency'. It is a calculated ratio of photon emissivity to ionisation rate, done separately for each metastable. So ionisation rates for each metastable are needed at the same time as the excitation rates. The same influx studies can be performed on the neutral species but there are some extra possibilities. Provided cross-section data at least up to the $n=4$ shell are available, visible spectrum line ratios of neutrals can yield electron density. This is because the collision limit at JET edge densities is around $n=4$ (2.l./.2.). Such a result is valuable since independent measurement of density is difficult. These inflowing ions are in a highly ionising plasma condition and in the evolution from one stage to another, metastable state population ratios differ from equilibrium values. In practice, this means that appropriate spectrum line ratios can characterise tempcrature and penetration distance into the plasma. Transient ionisation models nceded for the interpretation require metastable state selective ionisation coefficients and metastable cross-coupling coefficients in the generalised collisional-radiative sense $(2.1 .1 .1)$.

Influx of metals such as $\mathrm{Ni}$ and $\mathrm{Cr}$ in JET can also be characterised by visible spectral measurements on the neutral and singly ionised species. There are generally many metastable states for such ions in the $3 \mathrm{~d}^{n}, 3 \mathrm{~d}^{n-1} 4 \mathrm{~s}$ and $3 \mathrm{~d}^{n-2} 4 \mathrm{~s}^{2}$ configurations. Resonance transitions are suitable for observation but association of a line with excitation from a particular metastable is confused by configuration interaction, parentage breakdown etc. The availability of accurate excitation and ionisation cross-sections in this case is very low indeed (2.1.1.4). These are important aspects to improve. Although metal influxes are of less importance at the present time in JL: I due to the beryllium gettering campaigns, this arca will return into main analysis as divertor studies progress. In all these influx studies, usually the emitting ion is at an abnormally high temperature for its ionisation stage, so near threshold resonance regions of cross-sections are less important than in astrophysics.

4.2. DIVERTOR PLASMA. - This section is forward looking to the next step in the JET program for 1991-1994, when it is intended to construct a pumped divertor. Such an arrangement is designed to cause a flow in the peripheral plasma along open field lines to target plates in a divertor chamber. 
There the very large power flux can be radiated away cfficiently, sputtering of target plates minimised and impurities controlled. The divertor chamber plasma will be dense $\left(\mathrm{N}_{\mathrm{e}}<8 \times 10^{14}\right.$ $\left.\mathrm{cm}^{-3}\right)$ and of low temperature $\left(\Upsilon_{t} \sim 5-100 \mathrm{eV}\right)$. Dynamic ionisation and hlows will be characteristic of the plasma. The target material in JET will be beryllium, so beryllium and carbon will be the dominant impurity species. Future machines will however clcarly have to consider morc suitable enginecring materials such as molybdenum or tungsten. Studies with a range of species will be possible in JET, introduced by laser ablation in the divertor. Titanium and molybdenum are suitable to focus on with $3 \mathrm{p}^{n}$ and $4 \mathrm{p}^{n} 4 \mathrm{~d}^{\mathrm{m}}$ ions prominent respectively. Ionisation and recombination cocfficients are required as source terms for impurity ion transport models (2.2.1.2). For elements such as titanium or lighter, these are metastable resolved effective coefficients at finite density for the divertor conditions. Existing calculations for these more complex ions are probably of only modest reliability. Since the range of diagnostics in the divertor will be limited, it will be desirable to maximise the return from spectroscopy. This means that electron - ion collision data for density dependent line ratios and tomperature indicators are required. The quiet sun experience should be exploited here (2.2.1./). For heavy species such as molybdenum, bundling of ionisation stages into shell groups, identification of overlapped transition arrays from similar ions and spectral interval integrated observations of the pseudo - band spectra may be a fruitful approach (2.2.2.2).

4.3. BLLK PLASMA. - Central temperatures in JET are such that nickel, the main metallic impurity, is fully ionised. Spectral observations of resonance line emission in the X-ray, XUV and VUV of hydrogen-like to beryllium-like stages and then sodium-like and magnesium-like stages are the normal pattem. Standard analysis secks impurity concentrations and to this end, most simply, line intensities are merged empirically with bolometric and pulse height analysis measurements of total radiation. A fuller analysis computes the radial emission shells with an impurity diffusive transport model. This is a somewhat disappointing area from an atomic physics point of view. Over the years, broad and heavy requirements for atomic data have come from it - ionisation rates, dielectronic rates etc. for all ionisation stages of many species. Yet, apart from a few. exceptions (2.3.4.1), higher quality atomic data is not wcll exploited in this work, uncertainties in transport parameter variation and plasma symmetry confusing detailed comparisons.

Helium-like lines and associated three electron satellite lines are modelled in detail. The approach parallels that used in solar flares, namely matching of synthetic spectra. In JET, the width of the resonance line of NiXXVII is used for ion temperature, but the fixed X-ray line of sight coupled with differential rotation of the plasma and the annular shell of the cmission makes significant corrections necessary. Charge exchange spectroscopic data is used to help in this. The cross-section. data is largely worked out (2.3.3.1). I ine ratio studics involving forbidden lines in the boron-like and fluorine-like systems are relevant in fusion plasmas. Here it is the ion impact collisional transitions amongst fine structure lcvels which are the kcy, the object being deduction of ion tempcraturc or dcuterium dilution. In practice, the set of electron collision rates for the ion are also required. Choice of suitable species depends on the electron temperature. It is necessary in JET to work with quite heavy species to probe the core plasma, such as krypton (2.3.2.1). They are introduced by laser ablation or gas puffing, but restriction on allowable amounts to prevent disruptions inhibits spectroscopic measurements. Use of line ratios for electron density and temperature in the solar corona manner suffers from uncertain localisation and is in competition with lascr scattering, interferometry, electron cyclotron cmission and reflectometry.

In this rather negative view of the use made of good atomic rate data for the bulk plasma, it should be noted that absolutely calibrated measurements of radial emission shells would markedly alter the situation. There are some prospects of this in both the XUV and VLV at JEI.

\section{Energy level and transition probability data}

In this section it is only necessary to draw brief attention to one or two points. The availability of energy level and transition probability data far exceeds that of collision data, where the real bottlenccks to diagnostic progess lie.

5.1. EDGF, AND IIVERTOR PLASMA. - Most data required for light atom influx deductions from noutral and singly ionised ions are well known. However lifetimes of upper $n=3$ levels of observed transitions can be influenced by two-clectron transitions to $n=2$ complexes. A-values for these have sometimes proved unreliable (3.1.1.I). For metal influxes $(\mathrm{Cr}, \mathrm{Fe}, \mathrm{Ni}, \mathrm{Cu}$ ) from neutral and singly ionised ions, choice of lines for observation and calculation of branching ratios to parents rely heavily on large computer generated tabulations. Concems about cross-sections have so far inhibited much detailed consideration of accuracy and completeness here. This situation is improving (3.1.1.2). For heavy species (Mo, W), no start on spectral observations for influx has been madc yet. 
5.2. BULK PIASMA. - Spectral features in the VUV and XUV in metal rich plasma conditions can still remain unexplained. Further work on the detailed positions of transition arrays of heavy species is required (3.2.4.3). Forbidden line transition probabilities for studies described in section 4.3 are required and of special value would be identification of visible wavelength forbidden line markers of highly ionised heavy species in the plasma (3.2.2.2). Visible spectroscopic observations are convenient in fusion tokamaks. Remaining transition probability data needs, including Auger rates, relate to general ionisation and recombination of plasma impuritics (3.2.4).

\section{Conclusions}

The paper has focussed on the JI:I plasma and identified the detailed atomic data needs for its spectroscopic diagnostics. It should be noted however that other large scale fusion experiments tend to have very similar instrumentation and objectives. Thus although particular species invloved may differ sorncwhat ( $\mathrm{B}$ rather than $\mathrm{Bc}$, Fe rather then $\mathrm{Ni}$ etc.) the diagnostic methodology given here is likely to be followed. The next generation machines are expected to emphasise even more the edge and divertor regions as the resilience of materials to very high power loads and neutron fluxes is investigated. Also neutral beams are likely to be more energetic to improve penctration at high density, a direction in which ion-atom cross-section data is less uncertain. The stressing of higher precision data of a more selective sort given here is also likely to be the case in the future.

More precise power inventories are relevant to ignited or breakeven machines.

\section{References}

[1] A. Boileau, M. von I Iellermann, L.D. Horton \& II.P. Summers, Plasma Phys. \& Contr. Fusion 31, 779 (1989).

[2] M. von Hellermann, W. Mandl, H.P. Summers, A. Bojleau \& J. Fricling, Plasma Phys. \& Contr. Fusion - submitted (1990).

[3] A. Boileau, M. von Ifellermann, W. Mandl, H.P. Summers, H. Weisen \& A. Zinoviev, J. Phys. B 22, 1145 (1989).

[4] M. Mattioli, N.J. Peacock, H.P. Summers, B. Denne \& N.C. Hawkes, Phys. Rev. A40, 3886 (1989).

[5] K.II. Behringer, H.P. Summers, B. Denne, M. Forrest \& M.F. Stamp, Plasma Phys. \& Contr. Fusion 31, 2059 (1989).

[6] H.P. Summers, P. Thomas, R. Giannella, M. von Hellermann, P. Burke, B. Denne, W. Fritsch, N. Hawkes, W. Mandl, N.J. Peacock, R. Reid \& M.F. Stamp, Plasma Phys. \& Contr. Fusion - submitted (1990).

[7] K.-D. Tastrow, M. Darielsson. M. von Hellermann, E. Kallne, R. Konig, W. Mandl, H.W. Morsi \& H.P. Summers, Phy's. Rev. A. - submitted (1990).

[8] K.-D. Zastrow, E. Kallne, H.P. Summers, Phys. Rev. A41, 1427 (1990).

[9] H.P. Summers, K.H. Behringer \& 1. Wood, Physica Scripta 35, 303 (1987). 
Table la. - ion-atom collision data

\begin{tabular}{|c|c|c|c|c|}
\hline Primary area & $\begin{array}{l}\text { Secondary } \\
\text { area }\end{array}$ & Tertiary area & Study & lon-atom collision data \\
\hline \multirow[t]{5}{*}{$\begin{array}{l}(1 . l) \\
\text { Neutral } \\
\text { hydrogen } \\
\text { beams }\end{array}$} & $\begin{array}{l}(1 . l . I) \\
\text { Charactensing } \\
\text { of the beam }\end{array}$ & $\begin{array}{l}\text { (l.l.1.1) } \\
\text { Attenuabon } \\
\text { of the beam } \\
\text { in the plasma }\end{array}$ & $\begin{array}{l}\text { Local } n_{D} \text { in beam allowng } \\
\text { impunty density } \\
\text { deduction } \\
\text { vio stepunse processes }\end{array}$ & $\begin{array}{l}\mathrm{D}+\mathrm{D}^{+}, \mathrm{D}+\mathrm{He}^{+2}, \mathrm{D} \div \mathrm{Be}^{+4}, \\
\mathrm{D}+\mathrm{C}^{+6}, \mathrm{D} \div \mathrm{O}^{+8} \\
\mathrm{CX} \text { and ionis. } \\
\sigma_{\text {tot }} \cdot \text { ikev }<\mathrm{E} / \mathrm{amu}<140 \mathrm{kev}\end{array}$ \\
\hline & & $\begin{array}{l}\text { (I.l.1.2) } \\
\text { Radiaton by } \\
D \text { in the } \\
\text { beam } \\
{[3]}\end{array}$ & $\begin{array}{l}\sigma \& \mathrm{D} \alpha \text { measurements to } \\
\text { ohtan intemal B-field. } \\
\text { Excited } D \text { content of beam. } \\
\text { Deducton of } Z \text { eff. }\end{array}$ & 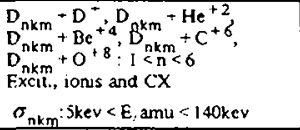 \\
\hline & & $\begin{array}{l}\text { (1.1.1.3) } \\
\text { Enhanced } \\
\text { attenuation } \\
\text { of the beam. }\end{array}$ & $\begin{array}{l}\text { Collisional radiagve calculation } \\
\text { of beam atenuation coefficients }\end{array}$ & As (1.1.1.2) above \\
\hline & & $\begin{array}{l}\text { (1.1.1.4) } \\
\text { Formation of } \\
\text { the beam } \\
\text { halo and its } \\
\text { effects }\end{array}$ & $\begin{array}{l}\text { Beam / halo conversion } \\
\text { Correction to plasma deuteron } \\
\text { density deduction due to halo }\end{array}$ & $\begin{array}{l}\mathrm{D}+\mathrm{D}^{+} . .>\mathrm{D}^{+}+\mathrm{D}_{\mathrm{nly}}: 0<\mathrm{n}<6 \\
\sigma_{\mathrm{n}}: 5 \mathrm{kev}<\mathrm{E} ; \text { amu }<140 \mathrm{kev}\end{array}$ \\
\hline & $\begin{array}{l}1.1 .21 \\
\text { Illumination } \\
\text { of plasma } \\
\text { ions \& } \\
\text { scrnped } \\
\text { impurities }\end{array}$ & $\begin{array}{l}\text { (I.I.2.I) } \\
\text { D \& stroped } \\
\text { light impunty } \\
\text { CX induced } \\
\text { line shapes } \\
{[2]}\end{array}$ & $\begin{array}{l}\text { Deductuon of local } \Upsilon_{\text {, for }} \mathrm{D}, \mathrm{He}, \\
\mathrm{Be}, \mathrm{C} \& \mathrm{O} \text { at radial pts. } \\
\text { Deduchon of local v } \\
\text { at radial pts. }\end{array}$ & As (1.I.2.2) below. \\
\hline & & $\begin{array}{l}(1.1 .2 .2) \\
C X \text { induced } \\
\text { cmissinties } \\
{[1]}\end{array}$ & $\begin{array}{l}\text { Deducton of local } n \text {, for } D, \text { He, } \\
\text { Be, } C \& O \text { at radial pts. }\end{array}$ & 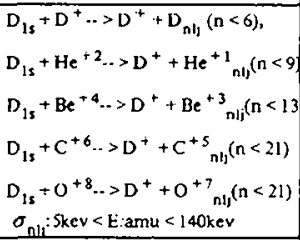 \\
\hline & & $\begin{array}{l}\text { (1.1.2.3) } \\
\text { Excited states } \\
\text { of } D \text { in beam }\end{array}$ & $\begin{array}{l}\text { Correctuon to } \mathrm{n}_{\text {, from } \mathrm{CX} \text { from }} \\
\text { excited } \mathrm{D} \text { in the beam }\end{array}$ & $\begin{array}{l}\text { As }(1.1 .2 .2) \text { from } D_{n k m} \\
(1<n<6) \text { as donor. }\end{array}$ \\
\hline & & $\begin{array}{l}\text { (1.1.2.4) } \\
\text { Inserfering } \\
\text { edge feanures } \\
{[1]} \\
\end{array}$ & $\begin{array}{l}\text { Subraction of concid. edge } \\
\text { fearures - isolate beam CX }\end{array}$ & $\operatorname{Sec}(1.2 .2 .1)$ \\
\hline & & $\begin{array}{l}(1.1 .2 .5) \\
\text { Alpha } \\
\text { particles } \\
{[2]} \\
\end{array}$ & $\begin{array}{l}\text { Deduction of } \alpha \text {-particle D.T } \\
\text { fusion source rate. Deducton of } \\
\alpha \text {-parncle D-T cooting distr. } \\
\text { function param. }\end{array}$ & $\begin{array}{l}\left.\mathrm{D}_{\left(\mathbf{j}^{3}\right.}+\mathrm{He}^{+2}<9\right) \\
\sigma_{\mathrm{nlj}} ; 5 \mathrm{kev}<\mathrm{E}, \text { amu }<300 \mathrm{kev}\end{array}$ \\
\hline & $\begin{array}{l}(1.1 .3) \\
\text { lonisation } \\
\text { balance and } \\
\text { transport }\end{array}$ & $\begin{array}{l}\text { (l.l.3.1) } \\
\text { Local } \\
\text { hal ance in } \\
\text { beam } \\
\text { traversed } \\
\text { region } \\
\end{array}$ & $\begin{array}{l}\text { Deducton of discrib. of ionsaton } \\
\text { stages of all impurity elements } \\
\text { when CX from beams active }\end{array}$ & See (I.1.3.2) below \\
\hline & & $\begin{array}{l}\text { (t.1.3.2) } \\
\text { Average } \\
\text { balance in } \\
\text { 1.D impunty } \\
\text { transport } \\
\text { modelling }\end{array}$ & $\begin{array}{l}\text { Deductuon of dismb. of ionisaton } \\
\text { stages of all impurty clements } \\
\text { averaged for } 1-D \text { modelling when } \\
\text { CX from beams active }\end{array}$ & $\begin{array}{l}\text { As (I.I.I.I) above extended to } \\
\text { Be-like stages including } \mathrm{Cl} \text { and } \\
\mathrm{N} 1 \text { at present. }\end{array}$ \\
\hline
\end{tabular}


Table 1b. - ion-atom collision data

\begin{tabular}{|c|c|c|c|c|}
\hline Primary area & $\begin{array}{l}\text { Secondary } \\
\text { area }\end{array}$ & Tetrary area & Study & lon:alom collision data \\
\hline \multirow[t]{8}{*}{$\begin{array}{l}\text { (1.2) } \\
\text { Thermal } \\
\text { hydrogen }\end{array}$} & $\begin{array}{l}\text { (1.2.1) } \\
\text { Propagation } \\
\text { of neutral D } \\
\text { into plasma }\end{array}$ & & $\begin{array}{l}\text { Deducion of density and decay } \\
\text { length of neutral hydrogen into } \\
\text { plasma. Scrape off layer energy } \\
\text { balance. }\end{array}$ & $\begin{array}{l}\mathrm{D}_{1 \mathrm{~s}}+\mathrm{D}^{+} \ldots>\mathrm{D}^{+}+\mathrm{D}_{\mathrm{nt}} \\
\left(0^{\circ} \mathrm{n}<6\right) \\
\sigma_{\mathrm{nl}}: \text { lev }<\mathrm{E} \text { amu }<10 \mathrm{kev}\end{array}$ \\
\hline & $\begin{array}{l}\text { (1.2.2) } \\
\text { Influence on } \\
\text { stripped light } \\
\text { impurities }\end{array}$ & $\begin{array}{l}(1.2 .2 .1) \\
C X \text { induced } \\
\text { emissinoes }\end{array}$ & $\begin{array}{l}\text { Deductoon of neutral hydrogen } \\
\text { density at plasma penphery }\end{array}$ & 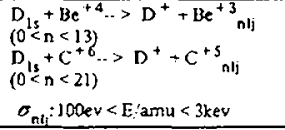 \\
\hline & & $\begin{array}{l}(1.2 .2 .2) \\
\text { Excited states } \\
\text { of } 1) \\
{[4]}\end{array}$ & $\begin{array}{l}\text { Direct investgaton of } \mathrm{CX} \text { from } \\
\text { excited states of } \mathrm{D} \text {. Consistency } \\
\text { with } \mathrm{D} \alpha \text { mcasurements }\end{array}$ & $\begin{array}{l}\text { As }(1.2 .2 .1) \text { but from } D_{n \mid} \\
(1<n<6)\end{array}$ \\
\hline & & $\begin{array}{l}\text { (1.2.2.3) } \\
\text { lonisation } \\
\text { balance }\end{array}$ & $\begin{array}{l}\text { Study of modufications of } \\
\text { ionsation balance at plasma } \\
\text { penphery due to } C X \text { from thermal } \\
\text { neutral hydrogen }\end{array}$ & 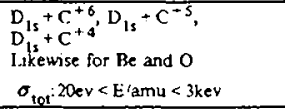 \\
\hline & $\begin{array}{l}\text { (1.2.3) } \\
\text { Influence on } \\
\text { partaally } \\
\text { strpped } \\
\text { impuntes }\end{array}$ & $\begin{array}{l}\text { (1.2.3.1) } \\
\text { Influx } \\
\text { deduced } \\
\text { from visible } \\
\text { spectroscopy }\end{array}$ & $\begin{array}{l}\text { Corrections io deduced influx } \\
\text { from CII, CIII, Oll, OlII vsible } \\
\text { spectra due to state selectove } \\
\text { capture from thermal D }\end{array}$ & $\begin{array}{l}D_{15}+C^{+3} \\
(n=3,4 \text { all substates) } \\
\text { also } C^{+2}, O^{+2} \text { and } O^{+3} \\
\sigma_{n 1^{+2}}: 20 e v<E \text {, amu }<200 \text { ev }\end{array}$ \\
\hline & & $\begin{array}{l}(1.2 .3 .2) \\
\text { VUV } \\
\text { spectral } \\
\text { emussion }\end{array}$ & $\begin{array}{l}\text { Direct investgaton of neutral } \\
\text { hydrogen density from CII, CIII, } \\
\text { OII, OIII VUV emusson } \\
\text { Correlaton of lnw and high } \\
\text { spectral senes members } \\
\end{array}$ & $\begin{array}{l}\mathrm{D}_{\mathrm{n}^{\prime}}+\mathrm{C}^{+3} \\
\left(4^{+3}<\mathrm{n}<13\right)^{8, m} \cdots>\mathrm{D}^{+}+\mathrm{C}^{+2} \mathrm{nl} \\
\sigma_{\mathrm{n}^{\prime}, \mathrm{n} \mathrm{n}^{\prime}} \text { lev }<\mathrm{E}: \text { amu }<200 \mathrm{ev}\end{array}$ \\
\hline & $\begin{array}{l}\text { 11.2.4) } \\
\text { Influence on } \\
\text { ncarly } \\
\text { stonpped } \\
\text { medium Z } \\
\text { species }\end{array}$ & & $\begin{array}{l}\text { Invest ganon of } C X \text { dimusionsion of } \\
\text { high seres members of } \\
\text { hellum.like resorance lines of } \\
\text { medium } 2 \text { elements. } \\
\text { Study of neutral D densty in } \\
\text { deeper layers }\end{array}$ & 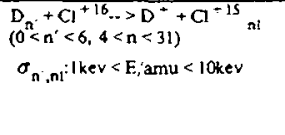 \\
\hline & $\begin{array}{l}(1.2 .5) \\
\text { lonisation } \\
\text { balance }\end{array}$ & & $\begin{array}{l}\text { General correction of } \\
\text { recombination rates for modelling } \\
\text { to include CX from thermal } \\
\text { hydrogen }\end{array}$ & $\begin{array}{l}\text { As }(1 . l .3 .2) \text { extended to singly } \\
\text { oonused species } \\
(0<\mathrm{n}<9) \\
\sigma_{10 \mathrm{i}}: 20 \mathrm{ev}<\mathrm{E}^{\prime} \text { amu }<\text { Skev }\end{array}$ \\
\hline \multirow[t]{3}{*}{$\begin{array}{l}(1.3) \\
\text { Neutral } \\
\text { helium } \\
\text { beams }\end{array}$} & $\begin{array}{l}(1.3 .1) \\
\text { As }(1.1) \text { with } \\
\text { helium }\end{array}$ & & & $\begin{array}{l}\text { As }(1,1,1,1),(1.1,1.2) \text { and } \\
(1.1 .2 .2) \text { but with lie replacing } \\
\text { D. }\end{array}$ \\
\hline & $(1.3 .2)$ & $\begin{array}{l}\text { (1.3.2.1) } \\
\text { Detection of } \\
\text { fusion al pha } \\
\text { particles }\end{array}$ & $\begin{array}{l}\text { Neutralisation of } D \cdot I \text { fusion } \\
\text { alpha particles by helium. }\end{array}$ & $\begin{array}{l}\mathrm{He}+\mathrm{He}^{+2} . .>\mathrm{He}^{+2}+\mathrm{He} \\
\sigma_{10 \mathrm{t}}: \mathrm{E} / \mathrm{amu}<880 \mathrm{ker}\end{array}$ \\
\hline & $\begin{array}{l}\text { (1.3.3) } \\
\text { Beam } \\
\text { formaton }\end{array}$ & $\begin{array}{l}\text { (1.3.3.1) } \\
\text { Neuraliser } \\
\text { design }\end{array}$ & $\begin{array}{l}\mathrm{He}^{*} ; \mathrm{He} \mathrm{neutralising} \text { and } \\
\text { metastable He content of beam. }\end{array}$ & 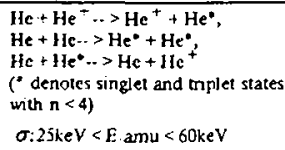 \\
\hline
\end{tabular}


Table 2a. - electron-ion collision data

\begin{tabular}{|c|c|c|c|c|}
\hline Prmary arca & $\begin{array}{c}\text { Secondary } \\
\text { arca }\end{array}$ & Tertiary area & Study & Flectron impact data \\
\hline \multirow[t]{4}{*}{$\begin{array}{l}\text { (2.l) } \\
\text { Edge plasma }\end{array}$} & $\begin{array}{l}(2 . I . I) \\
\text { Impunty } \\
\text { influx }\end{array}$ & $\begin{array}{l}(2.1 .1 .1) \\
\text { Influx of } \\
\text { light } \\
\text { impuntues } \\
\text { from limiters } \\
{[\vdots]}\end{array}$ & $\begin{array}{l}\text { Calculation of photon efficiencies } \\
\text { for BeI, Bell, CI, CIl, CllI, OI, } \\
\text { OII, Olll. } \\
\text { Finite density, restricted level } \\
\text { model }\end{array}$ & $\begin{array}{l}\mathrm{n}=2-2 \text { and } 2-3 \text { dipole \& } \\
\text { non-dipole } \mathrm{x} \text {-sects. from ground } \\
\text { \& metastables, LS-resolved. } 3-3 \\
\text { dupole } x \text {-sects. for coll. } \\
\text { redistn buton. Cascade following } \\
\text { cxcit. to } n>3 \text { must be estimated. } \\
30 \% \text { acc. on pnncipal excitations. } \\
10 \mathrm{eV}<\mathrm{E}<200 \mathrm{eV} \text {. }\end{array}$ \\
\hline & & $\begin{array}{l}(2.1 .1 .2) \\
\text { Diagnostucs } \\
\text { using light } \\
\text { neutrals. } \\
{[6]}\end{array}$ & $\begin{array}{l}\text { Electron density deductions from } \\
\text { BeI, CI \& OI. } \\
\text { Generalised collisional radiative } \\
\text { model. }\end{array}$ & $\begin{array}{l}\text { As }(2.1 .1 .1) \text { but with spin change } \\
x-s e c t s \text { and extended to hugher } n \text {, } \\
\text { LS-resolved to } n-4 \text {. Supplement } \\
\text { with bundle } n \text { excit. and ionis. } \\
x-s e c t s \text {. at high } n \text {. } \\
j e V<E<200 \mathrm{eV} \text {. }\end{array}$ \\
\hline & & $\begin{array}{l}(2.1 .1 .3) \\
\text { Dymamic } \\
\text { ionisazon. } \\
{[6]}\end{array}$ & $\begin{array}{l}\text { Calculaton of time dependerit } \\
\text { and/or spatal non-equilibrium } \\
\text { metastable populations for species } \\
\text { as above. } \\
\text { Generalised collisional tadiatuve } \\
\text { model. }\end{array}$ & $\begin{array}{l}\text { As }(2.1 .1 . t) \text { and }(2.1 .1 .2) \text { but } \\
\text { including inutial and final } \\
\text { metastable state selectuve } \\
\text { ionisation coefficients. Same } \\
\text { species. } \\
\text { seV }<\text { F }<300 \mathrm{eV} \text {. }\end{array}$ \\
\hline & & $\begin{array}{l}(2.1 .1 .4) \\
\text { infux of } \\
\text { metal. impur. } \\
\text { from limiters } \\
\& \text { antennae } \\
{[5]}\end{array}$ & $\begin{array}{l}\text { Calculation of photon efficiencles } \\
\text { for Crl, Crll, Fel, FelI, NiI, Nill }\end{array}$ & $\begin{array}{l}n:=3-4 \text { \& } 4-4 \text { dipole } x \text {-sects. } \\
\text { Parent \& metastable resolution } \\
\text { whth parent changing transitions } \\
\text { included. Initial state metastable } \\
\text { selective, ionssation } x \text {-sects. of } \\
\text { same precision. } 40 \% \text { acc. would } \\
\text { excecd any measurement } \\
10 \mathrm{eV}<\mathrm{E}<200 \mathrm{eV} \text {; }\end{array}$ \\
\hline \multirow[t]{4}{*}{$\begin{array}{l}\text { (2.2) } \\
\text { Divertor } \\
\text { plamsa }\end{array}$} & $\begin{array}{l}(2.2 .1) \\
\text { medum } \\
\text { weight metals }\end{array}$ & $\begin{array}{l}(2.2 .1 .1) \\
\text { Influx from } \\
\text { divertor } \\
\text { target plates }\end{array}$ & $\begin{array}{l}\text { Photon efficiencies for 'Iil and } \\
\text { rill. } \\
\text { Relevant species may change. }\end{array}$ & $\begin{array}{l}\mathrm{n}=3.4 \text { and } 4.4 \text { dipole, non-dipole } \\
\text { and spin change } x \text {-sects. Parent } \\
\text { changing } x \text {-sects. included. } 40 \% \\
\text { acc. } \\
5 e V<E<200 \mathrm{ev}\end{array}$ \\
\hline & & $\begin{array}{l}(2.2 .1 .2) \\
\text { lonisabon } \\
\text { balance, } \\
\text { radiated } \\
\text { power } \\
\end{array}$ & $\begin{array}{l}\text { Ionsatuon, recombination, } \\
\text { emissivites and dagnostic lise } \\
\text { ratos for } \mathrm{TiV} \text { - TiXI. } \\
\text { Generatised collisional radiative } \\
\text { model. }\end{array}$ & $\begin{array}{l}n-3-3,3-4 \text { and } 4.4 x \text {-sects. } \\
\text { Complete set. } \\
\text { Zero density state selective partial } \\
\text { drelectronic coefns. with inital } \\
\text { metastable distnquished. } 40 \% \\
\text { acc. } \\
j \mathrm{cV}<\mathrm{E}<200 \mathrm{eV} \text {; }\end{array}$ \\
\hline & $\begin{array}{l}(2.2 .2) \\
\text { Heavy } \\
\text { clements }\end{array}$ & $\begin{array}{l}(2.2 .2 .1) \\
\text { Influx from } \\
\text { divertor } \\
\text { plates }\end{array}$ & As $(2.1 .1 .4)$ for $\mathrm{Mol}$, Moll. & Detailed needs undefined \\
\hline & & $\begin{array}{l}(2.2 .2 .2) \\
\text { Ionisation } \\
\text { balance, } \\
\text { radiated } \\
\text { power }\end{array}$ & $\begin{array}{l}\text { Shell group approach to ionsation } \\
\text { and recombination ticd to pseudo- } \\
\text { band emission including .Mo, W. }\end{array}$ & $\begin{array}{l}\text { Ionis. incl. multiple autoionis., } \\
\text { recom. and excit. } x \text {-sects for Mo } \\
\& W \text { rons to } n-3 \text { shells and } n=4 \\
\text { shells resp. } \\
\text { Factor } 2.3 \text { accuracy. } \\
\text { leV }<E<1 \mathrm{keV} \text {. }\end{array}$ \\
\hline
\end{tabular}


Tablc 2b. - electron-ion collision data

\begin{tabular}{|c|c|c|c|c|}
\hline Prmary area & $\begin{array}{l}\text { Secondary } \\
\text { area }\end{array}$ & Teroary area & Study & Electron impact data \\
\hline \multirow[t]{7}{*}{$\begin{array}{l}\text { (2.3) } \\
\text { Bulk plasma }\end{array}$} & $\begin{array}{l}2.3 .1) \\
\text { L.ght } \\
\text { impunty } \\
\text { densitues }\end{array}$ & $\begin{array}{l}\text { (2.3.l.1) } \\
\text { Charge } \\
\text { excharge } \\
{[4]}\end{array}$ & $\begin{array}{l}\text { Studies of Lyman series and } \\
\Delta n=1,2 \text { lines of } H \text {-llke tons } \\
\text { Contrast of clectron impact and } \\
\text { CX processes for edge feanures }\end{array}$ & $\begin{array}{l}\text { Excil. } x \text {.sects. from } n=1,2 \text { to high } \\
\text { n, I-resulved at } 20 \% \text { accur. } \\
\text { He, Bc.C \& O man species. } \\
100 \mathrm{c} V<\mathrm{E}<5 \mathrm{keV}\end{array}$ \\
\hline & & $\begin{array}{l}(2.3 .1 .2) \\
\text { Radiation hy } \\
D \text { in the } \\
\text { neutual } \\
\text { heams } \\
{[3]}\end{array}$ & $\begin{array}{l}\sigma \& \pi \text { D measurements to obtain } \\
\text { Internal } B \text {-field; full, } 1: 2 \text { and } 1 / 3 \\
\text { energy beam attenuation measure; } \\
\text { excited D content of beam; Zeff } \\
\text { measure }\end{array}$ & $\begin{array}{l}\text { Excit. } x \text {-sects. from } n-1 \text { to } \\
n-2,3,4 \text {. Differenoal } x \text {-sects. in } \\
\text { stakk state pucture. } \\
\text { sev }<\mathrm{E}<\mathrm{lkeV}\end{array}$ \\
\hline & $\begin{array}{l}i 2.3 .2) \\
\text { VUV \& } \\
\text { EUV } \\
\text { diagnostics }\end{array}$ & $\begin{array}{l}\text { (2.3.2.1) } \\
\text { Jon } \\
\text { temperature! } \\
\text { deutenum } \\
\text { dilutoon }\end{array}$ & $\begin{array}{l}\text { Lse af boron-like ground tcrm } \\
\text { fine structure mixng by ion } \\
\text { collsions. } \\
\text { Applies also to fluorine-tike. }\end{array}$ & $\begin{array}{l}\text { Excit. } x \text {-sccts. whthin ground } \\
\text { complex at } 20 \% \text { accur. } \\
\text { Ni. Kr. Mo } 10 \text { s } \\
\text { lkeV }<\mathbf{E}<10 \mathrm{kcV}\end{array}$ \\
\hline & $\begin{array}{l}(2.3 .3) \\
X \cdot \text { ray } \\
\text { dagnostocs }\end{array}$ & $\begin{array}{l}\text { (2.3.3.1) } \\
\text { lon \& } \\
\text { electoon } \\
\text { temperature, } \\
\text { lonsabon } \\
\text { balance } \\
{[?] \&[8]}\end{array}$ & $\begin{array}{l}\mathrm{Ni}_{1}+26 \text { lines and associated } \\
\text { satclltites. Line rabo compansons. } \\
\text { Applies also to } \mathrm{Cl}\end{array}$ & $\begin{array}{l}\text { Consistent excit. \& diel. } x \text {-sects. } \\
\text { at } 10 \% \text { accur. } \\
\text { All cncrgies. }\end{array}$ \\
\hline & $\begin{array}{l}(2.3 .4) \\
\text { General } \\
\text { plasma } \\
\text { simulaton. }\end{array}$ & $\begin{array}{l}(2.3 .4 .1) \\
\text { Dielectronic } \\
\text { recombinaton } \\
{[9]}\end{array}$ & $\begin{array}{l}\text { Dielectrunic coeffis. for } \\
\text { generalised collisional raduatuve } \\
\text { models } \\
\text { He, Be, C, O, Fe, Ni main } \\
\text { elements }\end{array}$ & $\begin{array}{l}\text { Zcro density total cocflis. } \\
\text { Metastable parent and spin } \\
\text { system resolved. } \\
\text { State selecuve low } n \text { values. } \\
\text { Parent changing } A_{r} \& A_{x} \\
\text { behanour muth } n \text {. } \\
20 \% \text { acr. for shell boundary ions. } \\
\text { All tempcratures }\end{array}$ \\
\hline & & $\begin{array}{l}\text { (2.3.4.2) } \\
\text { lonsatuon }\end{array}$ & $\begin{array}{l}\text { Ionusaton coefins. For generatised } \\
\text { collisional radiative models } \\
\text { He, Be, } \mathrm{C}, \mathrm{O}, \mathrm{Fc}, \mathrm{N} \text { mann } \\
\text { elements }\end{array}$ & $\begin{array}{l}\text { Metastable to metastable X-sects. } \\
\text { Dircct x-sects., inner shell excit. } \\
\text { x-sect., Augger raduative } \\
\text { branching, resolved initial \& linal } \\
\text { states } \\
20 \% \text { acc. as above } \\
\text { All temperatures }\end{array}$ \\
\hline & & $\begin{array}{l}(2.3 .4 .3) \\
\text { kadtated } \\
\text { power, line } \\
\text { emission }\end{array}$ & 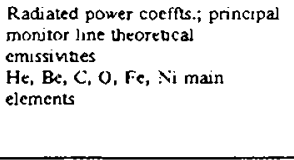 & $\begin{array}{l}\text { Proncipal excit. } x \text {-sects. for } \\
\text { coll, rad. modelling, metastable } \\
\& \text { spin system coupling } x \text {-sects. } \\
40 \% \text { acc. on cach ion. stage } \\
\text { powcr \& } 20 \% \text { on principal } \\
\text { ernissindes. } \\
\text { All temperaures } \\
\end{array}$ \\
\hline $\begin{array}{l}(2.4) \\
\text { Special } \\
\text { studies }\end{array}$ & $\begin{array}{l}(2,4.1) \\
X \text {-ray } \\
\text { diagnosncs }\end{array}$ & $\begin{array}{l}(2.4 .1 .1) \\
\text { Non-thermal } \\
\text { electron } \\
\text { distrbutoons } \\
\&>20 \mathrm{keV} \\
\text { temperature } \\
\text { studies }\end{array}$ & $\begin{array}{l}\text { Kunematc relaturistic corrections } \\
\text { to } x \text {-sects. }\end{array}$ & $\begin{array}{l}\text { excit. x-sects. whth revised } \\
\text { asymptotic behanour \& high } \\
\text { energy projection; dipole \& } \\
\text { non-dipole. }\end{array}$ \\
\hline
\end{tabular}


Table 3. - energy/A-value data

\begin{tabular}{|c|c|c|c|c|}
\hline Pnmary area & $\begin{array}{l}\text { Secondary } \\
\text { area }\end{array}$ & Tertary area & Study & $\begin{array}{c}\text { Energy \& transiton probability } \\
\text { data }\end{array}$ \\
\hline \multirow[t]{7}{*}{$\begin{array}{l}(3.1) \\
\text { Idgc and } \\
\text { divertor } \\
\text { plasma }\end{array}$} & $\begin{array}{l}(3 . I . I) \\
\text { Visible } \\
\text { spectroscopy }\end{array}$ & $\begin{array}{l}\text { (3.1.I.1) } \\
\text { Influx of } \\
\text { light } \\
\text { impuriues } \\
\text { from limuters }\end{array}$ & $\begin{array}{l}\text { Deduction of swatable lines \& } \\
\text { photon efficiencies for Bel, BeII, } \\
\text { CI, CII, ClIl, OI, OII, OIII }\end{array}$ & $\begin{array}{l}n=3-3 \& 4-3 \text { A-values; } 2 \text {-electron } \\
\text { transition probs. from } n=3 \\
\text { cascade paths from } n<7\end{array}$ \\
\hline & & $\begin{array}{l}(3 . I . I .2) \\
\text { Influx of } \\
\text { metal impur. } \\
\text { from limiers }\end{array}$ & $\begin{array}{l}\text { Deduction of sutable lines \& } \\
\text { photon efficiencies for CrI, CrIl, } \\
\text { FeI, Fell, NiI, Nill } \\
\text { Extend to Til \& Till. }\end{array}$ & $\begin{array}{l}\text { Association } \rho \text { fines with } \\
\text { metastables; } A \text {-values; branching } \\
\text { to different metastables; parent } \\
\text { mixang }\end{array}$ \\
\hline & & $\begin{array}{l}\text { (3.1.1.3) } \\
\text { Fluxes of } \\
\text { heavy } \\
\text { elements in } \\
\text { divertors }\end{array}$ & $\begin{array}{l}\text { As (3.I.I.2) above.. } \\
\text { Mol, Moll, WI, WII }\end{array}$ & Detailed needs undefined. \\
\hline & & $\begin{array}{l}\text { (3.t.I.4) } \\
\text { Thermal } \\
\text { deuterium }\end{array}$ & $\begin{array}{l}\text { Endence of CX from excited } \\
\text { states of D to fully ionised and } \\
\text { helium- like cons }\end{array}$ & $\begin{array}{l}\text { Energies of high nl levels of } \\
\text { lithium-like ions in terms of } \\
\text { polarisabilites }\end{array}$ \\
\hline & $\begin{array}{l}\text { (3.t.2) } \\
\text { VUV \& } \\
\text { EUV }\end{array}$ & $\begin{array}{l}\text { (3.t.2.I) } \\
\text { Thermal } \\
\text { hydrogen }\end{array}$ & $\begin{array}{l}\text { Evidence of CX from ground \& } \\
\text { excited states of D to partally } \\
\text { stripped light impuntes }\end{array}$ & $\begin{array}{l}\text { As }(3 . I . I . I) \text { extended to } 2<\mathrm{n} \\
<6 \text {. } \\
\text { Include Auger probabilities from } \\
\text { excited parents. }\end{array}$ \\
\hline & & $\begin{array}{l}(3.1 .2 .2) \\
\text { Radiated } \\
\text { power by } \\
\text { heavy species } \\
\text { in divertors }\end{array}$ & $\begin{array}{l}\text { Stages, raduat power, observable } \\
\text { spectral features for } 10-200 \mathrm{eV} \\
\text { plasma. Shell group / pseudo. } \\
\text { band structure approach? }\end{array}$ & $\begin{array}{l}\text { Energies \& A-values for } \\
\text { describing integral emission of } \\
\text { pseudobands and shell-shell } \\
\text { ionis./recom. Mo, W }\end{array}$ \\
\hline & $\begin{array}{l}\text { (3.1.3) } \\
\text { Spccial } \\
\text { studies }\end{array}$ & $\begin{array}{l}\text { (3.1.3.1) } \\
\text { Ion surface } \\
\text { interacton }\end{array}$ & $\begin{array}{l}\text { Secondary electron errission by } \\
\text { impact of highly ionised ions on } \\
\text { graphitc \& metal surfaces }\end{array}$ & $\begin{array}{l}\text { Radiat.;Auger probs. \& cascade } \\
\text { paths for mulo - spectator \& } \\
\text { strongly corret. neutralisation for } \\
\mathrm{Be}^{+4}, \mathrm{C}^{+6} \text { etc. }\end{array}$ \\
\hline $\begin{array}{l}(3.2) \\
\text { Bulk plasma }\end{array}$ & $\begin{array}{l}\text { (3.2.1) } \\
\text { Visible } \\
\text { spectroscopy }\end{array}$ & $\begin{array}{l}\text { (3.2.1.1) } \\
\text { Bremsstrahiung } \\
\text { emussion }\end{array}$ & Deduction of local Zeff & free-free Gaunt factors. \\
\hline \multirow[t]{5}{*}{. } & $\begin{array}{l}(3.2 .2) \\
\text { VLV \& } \\
\text { EUV } \\
\text { diagnostics }\end{array}$ & $\begin{array}{l}(3.2 .2 .2) \\
\text { Line ratio } \\
\text { diagnostics }\end{array}$ & $\begin{array}{l}\text { Deuterium diluton from } \\
\text { boron-like line ratios in } \mathrm{Ni}^{+23} \& \\
\mathrm{Kr}+31 \\
\text { Also fluorine-like. }\end{array}$ & 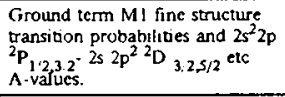 \\
\hline & $\begin{array}{l}(3.2 .3) \\
\text { XUV \& } \\
\text { X-ray } \\
\text { diagnostes }\end{array}$ & $\begin{array}{l}(3.2 .3 .1) \\
\text { Ion } \\
\text { temperature, } \\
\text { plasma } \\
\text { rotation and } \\
\text { transpont }\end{array}$ & $\begin{array}{l}\text { Plasma heatng, electron-ion } \\
\text { thermalisation and dynamic } \\
\text { ionisation state. } \\
\mathrm{Cl} \text { and } \mathrm{Ni} \text { man specics. } \\
\text { especially helium-like stages. } \\
\text { Fxtension to added species. }\end{array}$ & $\begin{array}{l}\text { Resonance, forbidden, intercomb. } \\
\text { \& satellite line parameters }\end{array}$ \\
\hline & $\begin{array}{l}(3.2 .4) \\
\text { General } \\
\text { plasma } \\
\text { simulation. }\end{array}$ & $\begin{array}{l}\text { (3.2.4.1) } \\
\text { Dielectronic } \\
\text { recombination } \\
{[9]}\end{array}$ & $\begin{array}{l}\text { Dielectronuc coefits. for } \\
\text { generalised collisional radiative } \\
\text { models } \\
\text { He, Be, } \mathrm{C}, \mathrm{O}, \mathrm{Fe}, \mathrm{N} \text { i main } \\
\text { elements }\end{array}$ & $\begin{array}{l}\text { Very high Rydberg state energy } \\
\text { level separations - dipole } \\
\text { polarisabilines with ground \& } \\
\text { metastable cores; A-values }\end{array}$ \\
\hline & & $\begin{array}{l}(3.2 .4 .2) \\
\text { Radiatuve } \\
\text { recombination }\end{array}$ & $\begin{array}{l}\text { Radiatve recombination coeffts. } \\
\text { for generalised collisional } \\
\text { radiative models } \\
\text { He, Be, } \mathrm{C}, \mathrm{O}, \mathrm{Fe}, \mathrm{Ni} \text { main } \\
\text { elemeris }\end{array}$ & $\begin{array}{l}\text { Zero density total coefficients. } \\
\text { Metastable parent and spin } \\
\text { system resolved. } \\
\text { State selective low n values } \\
20 \% \text { accur. } \\
\text { All temperatures }\end{array}$ \\
\hline & & $\begin{array}{l}(3.2 .4 .3) \\
\text { Radiated } \\
\text { power by } \\
\text { heavy species }\end{array}$ & $\begin{array}{l}\text { Idenufication of obscrvable } \\
\text { features in the XUV and EUV } \\
\text { Arbitrary species }\end{array}$ & $\begin{array}{l}\text { Energies \& } A \text {-values for } \\
\text { descnbing transition amay } \\
\text { emission for higher charge statcs } \\
\text { especially } n=3 \text { and } 4 \text { shells. }\end{array}$ \\
\hline
\end{tabular}

